\title{
The St. Andrews Marine Laboratory (under the Fishery Board for Scotland).
}

\author{
By Prof. MeIntosh, F.R.ร.
}

\section{Preliminary Remaris.}

ST. ANDREWs as a site for the study of marine animals has a reputation probably at least as ancient as the foundation of its University (the oldest Scottish, viz. 1411), for amongst the early records of the latter allusion is made to the marvels of the sea and its inhabitants as a means for improving the minds of its students. For a long time, however, no special lectures on natural history were given. The scientific advantages of the situation, indeed, were first prominently recognised by Edward Forbes and the brothers Goodsir. Thus the former, for instance, picked up, for the first time in Britain Echiurus, on the sands after a storm; and the two Goodsirs, as students, were familiar with its marine rarities, and afterwards read many zoological papers at its Literary and Philosophical Society. Prof. John Reid, the physiologist, studied the development of zoophytes and mollusks in its rock pools, and Prof. G. E. Day, his successor in the Chair of Anatomy and Physiology, and Miss Otté, lost no opportunity of interesting the stadents in marine zoology. Besides, the occupants of the Chair of Natural History from its foundation in 1753, and including Professors Vilant, Dick, Forrest, Cleghorn, Adamson, Ferrie, Macdonald, and Nicholson, as well as Dr. McVicar, the University lecturer, all more or less drew from the rich marine resources in their proximity.

It is long since efforts were made in the direction of founding a biological station at St. Andrews, and by one at least this has been steadily.kept in view since studentdays in 1853-57. On an opportunity presenting itself in the beginning of 1875 the subject was again advocated, and 
it was only the accident of an election that prevented the foundation of the Marine Laboratory that year. At this time Dr. Dohrn, of the Naples Zoological Station, cordially endorsed the proposal, and alluded to the University as, by "its position near the sea, inviting more than any other to the now all important study of marine zoology." Such a station, moreover, would be extremely useful "in educating young naturalists to take vigorously in hand the anatomy, histology, and embryology of marine animals, since there is scarcely a more appropriate place in Scotland for this study. I know it well enough," he added, "having passed more than one holiday near the venerable University, and hope to do so once more this summer."

In 1882 the practical zoological laboratory in the University was used as a marine laboratory, and efforts were made to obtain part, viz. $£ 300$, of the surplus (about $\mathfrak{E} 1800$ ) from the Edinburgh Fisheries Exhibition for the erection of a special marine laboratory. The whole of the surplus, however, was required for the Granton Marine Laboratory.

Efforts, nevertheless, were continued, and the experiments in St. Andrews Bay and elsewhere along the eastern shores in connection with H.M. Trawling Commission (1884-85) gave additional impetus to the movement. At last the Government, mainly at the instigation of the late Earl of Dalbousie, early in 1884, granted a sum to be devoted to this purpose through the Fishery Board for Scotland, and an immediate commencement was made by taking a lease of a wooden building between the barbour and the beach and fitting it with tanks, pipes, gas-engine, and pump, while the services of a trained fisherman were also obtained.* Even before the fittings were in order many observations in connection with the trawling work were carried out by aid of a temporary apparatus formerly used in salmon-hatching near the Tay. These operations are embodied in the Trawling Report. $t$ Amongst the rarer forms procured for the Labora-

* A brief account of the structure of the Laboratory is given in the "Third Annual Report of the Fishery Board for Scotland,' 1885.

+ 'Report of the Commissioners, Trawl, Net, and Bcam-Trawl Fishing, 1885,' Lord Dalhousie, chairman. 
tory this year (1884) was a new fish to British waters, viz. Lumpenus lampetriformis, Walb., a form well known in Norwegian waters, several specimens of which, all less in size, have since been obtained by trawlers in the Moray Frith. The somewhat scarce Cottus quadricornis was also obtained and many rare invertebrates, e.g. Corymorpha amongst the Zoophytes; the anemones Stomphia and Harmathia; Hippasterias amongst Echinoderms ; Pleurophyllidia and the egg-capsules of Fusus norvegicus. The advantages afforded by the Laboratory were also utilized this year (1884) by Professors Ray Lankester and Hubrecht (of Utrecht), and Mr., now Prof., A. G. Bourne. The first-mentioned worked upon a unique Gephyrean (Golfingia McIntoshii), $\dagger$ Prof. Hubrecht devoted himself to the Nemerteans, while Mr. Bourne examined the development of the Mollusca. Mr. (now Rev. R.) Gillespie, Demonstrator of Zoology at the University, also materially aided in carrying out the work in connection with the Royal Commission on Trawling. There can be no question that the latter observations were greatly facilitated by the conveniences of the Laboratory; for the boats bringing ova of the food-fishes procured at sea, and other living products of the expeditions, could approach within a few yards of the Laboratory-where further study of the living specimens could take place.

This year also the reproductive organs of the common mussel were examined from January to July, and an abstract published $\ddagger$ early next year along with some observations on the British species of Cyanea. $\$$

In the following year (1885) the observations on the reproduction and development of fishes received a fresh impetus from the labours of Mr. Edward E. Prince,\| who, under Prof. McIntosh, worked at the subject till September.

*Vide account of the specimen by F. Day, 'Proceed. Zool. Soc., June 17th, 1884.

+ 'Trans. Linn. Soc.,' 2nd ser., “ Zool.," vol. ii, pt. 16, 1885.

$\ddagger$ 'Ann. Nat. Hist.,' 3rd ser., vol. xiv, p. 149, Feb., 1885.

$\S \mathrm{A}$ brief note on the same appeared in the ' 3 rd Annual Report of the Fishery Board.'

II Vide papers, 'Ann. Nat. Hist.,' Dec., 1885, and May, 1886.

IT See 'Nature,' A pril, 1885 ; 'Annals of Nat. Hist.,' June, 1885, 1 plate. 
The food-fishes received the first attention, such as the cod, haddock, whiting, ling, eel, flounder, dab, gurnard, herring, and others; while the lump-sucker, viviparous blenny, catfish, short-spined Cottus, armed bull-head, bimaculated sucker, Montagu's sucker, dragonet, rockling, glutinous hag, sandeel, Gastrosteus spinachia, \&c., were also examined. The pelagic ova of the majority of the food-fishes were made the subject of special investigation. The multiple tumours of plaice and the flouuder also received notice. Some experiments were further made on phosphorescence and the results embodied in the President's address to the Biological Section of the British Association.* Additional observations on the development of the mussel were carried out this year by Mr. John Wilson.†

Other published observations included remarks on a new British Staurocephalus, peculiar processes formed by Cerapus on Tubularia, on certain ova, probably of a Cephalopod, according to Mr. Hoyle, from the Forth, and on the milk of the porpoise (chemically examined by Prof. Purdie).

Prof. Cleland, of Glasgow, lastly, made some anatomical researches on the tail of Myxine. $f$

The capture of a very fine tunny towards the end of the year bf a Granton trawler, enabled some observations to be made on a fresh example of this rare fish, about nine feet in length, $\S$ and the skeleton will probably form the subject of a subsequent communication.

The researches on the derelopment and life-histories of the fond-fishes were continued by Prof. McIntosh and $\mathrm{Mr}$. Ed. E. Prince in 1886, in the beginning of which year a noteworthy capture of a huge mass of the large demersal eggs of the catfish (Anarrlichas lupus) was made in St. Andrews Bay. The embryos were far advanced in these eggs, but a tolerably complete history of this form was drawn up by aid of these specimens, and they were kept in

- 'Report, Brit. Assoc.,' 1885.

+ Vide 'Report, Brit. Assoc.,' 1885, and 'Report, Fishery Board for Scotland,' 1886.

I 'Report Brit. Assoc.,' 1885.

§ 'Aum. Nut. Hist., A pril, 1886, and June, 1886. 
the Laboratory till the commencement of the post-larval stage. The pelagic eggs of the ling were procured in considerable numbers at sea by aid of a liner, who fertilized the ova, and transmitted them to the Laboratory. Further remarks were also made on the tunny, on the affinities of the poor or power cod, and the bib, on the weevers, on the parental instincts of Cyclopterus, on the very young cod and other food-fishes, on the capture of food-fishes by the liners, on the injuries to baited hooks and to fishes on the lines, on shrimp-trawling and sprat-fishing, on the ora of a number of other fishes, on the effect of storms on the marine Fauna, and on certain invertebrates, including forms used as bait.* Remarks on an abnormal Hydromedusa (Thaumantias) devoid of mouth were also communicated to the British Association. Some experiments on the preservation of mussels for bait were likewise carried out at the Laboratory, proving that by the aid of a solution of such a substance as boro-glyceride they can be kept for a period of several weeks in winter (after they have been put on the lines) and for a shorter period in summer. Moreover, it was found that the use of such a preservative does not seem to impair the usefulness of the bait on the fishing grounds.

This year Mr. Wilson further extended his observations on the development of the mussel (Mytilus edulis), while Dr. Scharff, now of the Museum of the Royal College of Science, Dublin, carried out an interesting inquiry into the ovarian ova of Teleosteans. Mr. E. E. Prince further published papers on the early stages in the development of the foodfishes, on oleaginous spheres in the yolk of Teleostean ova, and on the development of the pectoral fins in Teleosteans.

The use of a huge midwater net made at the Laboratory greatly facilitated the study of the life-histories of the foodfishes and other forms.

In 1887 the researches on the development of Teleosteans were further extended, especially in regard to post-larval stages, the use of the large mid-water net on board the Fishery steamer "Garland" and also in the Yawl "Dal-

- Vide 'Ann. Nat. Hist.,' May, June and August, 1886 ; 'Nature,' 1886, and ' Report to Fishery Board for Scotland,' 1886. 
housie" being attended with noteworthy results. Besides aiding Prof. McIntosh with this work, Mr. E. E. Prince communicated further researches "On the Teleostean Pectoral Fin" to the British Association, "On the Development of the Ovary and Oviduct in Certain Osseous Fishes," "On the Luminous Organs of the Pearl-sides," and "On the Structure of Tomopteris." Other papers from the Laboratory (by Prof. McIntosh) were, "On the Pelagic Fauna of our Shores in its Relation to the Nourishment of the Young Fishes," "On the Occurrence of Peculiar Gelatinous Bodies in Profusion," "On Syncoryne decipiens," "On the Commensalistic Habits of the Larval Forms of Peachia," "On the Presence of Swarms of Appendicularias," and "On the Occurrence of Clione borealis in St. Andrews Bay.t Further remarks were given on postlarval fishes, young gunnel, Liparis and Labrus. $\neq$ A considerable paper, with three plates, was written by Mr. E. E. Prince on his "Researches on the Development and Morphology of the Limbs of Teleosts." This will be published soon in America. $\S$

Prof. Burdon Sanderson and Mr. Gotch, of Oxford, for some time in summer carried out a series of interesting physiological researches on the electrical organs of the skate (chiefly the thornback and grey skate), and as the fishes had to be not only living but perfectly fresh, the advantages of the Laboratory in this respect were conspicuous. Mr. H. E. Durham, B.A., of Cambridge, again, conducted various minute investigations into the life-history and functions of the perivisceral corpuscles of the starfishes (Asterias, \&c). Prof. D. J. Cunningham, of Trinity College, Dublin, commenced an inquiry into the vertebral column of young Teleosteans, while Prof. Purser, of the same University, studied the physiology of various invertebrates. Lastly, Dr. Gunn, of Moorfields Ophthalmic Hospital, London, began in February an inquiry at the Laboratory into the

\footnotetext{
* 'Ann. Nat. Hist.,' F'eb., 1887.

+ Ibid., August, 1887.

$\$$ Ibid., Oct., 1887.

$\S$ Elizabeth Thompson Fund.
} 
minute structure of the Teleostean eye, from the early embryo onwards. He is still busy with this research.

Besides the marine researches carried out since the opening of the Marine Laboratory, it is necessary to point out that many previous zoological inquiries had been made at St. Andrews. These are indicated in the 'Marine Invertebrates and Fishes of St. Andrews,' in the 'British Annelids,' Part I (Ray Society), and other publications ; and that numerous specimens have been freely sent to scientific workers at home and abroad, as well as to the British Museum and other collections.

While the main purpose of the establishment is the increase in our knowledge of the food-fishes, edible invertebrates, and all that relates to them, it is self-evident that a knowledge of the intricate environment of these cannot be satisfactorily made without a series of collateral researches into various departments of marine zoology, and, therefore, the work has been carried out on a broad basis. The practicability of increasing the supply of marine fishes of value, e. $g$. the sole, in places where it is only rarely met with, has never been lost sight of ; and though the Fishery Board have not yet granted the necessary aid of a steamer, it is to be hoped that this obstacle will soon be overcome. The closure of the bay, as insisted on in the 'Trawling Report,' would give most favorable opportunities for such experiments.

A large series of original coloured drawings, of great beauty (by the late Mrs. Günther), and a mass of MS. in connection with the monograph on the 'British Annelids,' for the Ray Society, are in hand. The collection of specimens (in spirit and microscopic) in connection with this work is also very extensive.

It may, in conclusion, be mentioned that the life-histories of the important food-fishes, such as the cod, haddock, whiting, ling, green-cod, gurnard, bib, poor cod, various flat fishes (Pluronectidx), catfish, and others, have been more or less completely followed from the egg onward. This is more difficult than it at first sight appears, for it is only by prolonged use of such an apparatus as the large midwater net-inshore and in deep water-that reliable data 
can be obtained. The early post-larval stages of several of the important round fishes so closely resemble each other that even now there is a margin for doubt. It is only when distinctive structural features or characteristic tints make their appearance that certainty is obtainable.

The proximity of the important mussel-beds at the mouth of the Eden has afforded opportunities for investigating the development and life-history of this species, and also for carrying out experiments in mussel cultivation. These will be embodied in a report on the subject for the managers (Town Council of St. Andrew's).

The great advantages of easy access to the University Museum and University Library have been from the first conspicuous, and a source of satisfnction and benefit to the workers. It would, indeed, be difficult to over estimate the privileges of the Marine Laboratory in these respects.

List of papers published since the opening of the St. Andrews Marine Laboratory up to and including 1887.

1. Report I to the Fishery Board for Scotland, 1884.

2. Report on Trawling at the request of Lord Dalhousie, Chairman of the Trawling Commission, 1884-85.

3. Report II to the Fishery Board for Scotland, 1885. (1 Plate.)

4. Report III to the Fishery Board for Scotland up to 31st December, 1885.

5. Report IV to the Fishery Buard for Scotland (year 1886), 1887.

The foregoing by Prof. McIN Tosn.

6. On the Occurrence of Lumpenus lampetriformis off the East Coast of Scotland, by Francis Day. Proceed. Zool. Soc., 1884, p. 445. (1 Plate.)

7. Notes from the St. Andrews Marine Laboratory, I. A. On the British species of Cyanea. B. On the Reproduction of Mytilus edulis.-Prof. McIntosh, Ann. Nat. Hist., Feb., 1885.

8. Notes from the same, II. On the Spawning of certain Marine Fishes (Herring, viviparous Blenny, Catfish, short-spined Cottus, armed Bullbead, bimaculated Sucker, and Montagu's Sucker); On Pelagic Ova, the Young of the Ling and the Eel. (1 Plate.) -Ibid., Ann. Nat. Hist., June, 1885.

9. Lecture on the Ova of Fishes.-Ibid., Nature, April, 1885.

10. The Phosphorescence of Marine Animals, the Presidential Address to the Biological Section of the British Association, Sept. 1885. -Ibid.

11. Notes from the St. Andrew's Laboratory, III. A. On the Ova of Callionymus lyra. B. On a new British Staurocephalus. c. On certain Processes formed by Cerapus on Tubularia indivisa. D. On certain Peculiar Ova from the Forth. E. On a Female Porpoise. (1 Plate.)-Prof. McIrtosh. 
12. Note on the Chemical Composition of the Milk of the Porpoise.Prof. Purdie, Ann. Nat. Hist., December, 1885, and Chemical News.

13. On the Development of the Food.Fishes at the St. Andrews Marine Laboratory.-E. E. Prince, Rep. Brit. Assoc., 1885, p. 1091.

14. On the Nest and Development of Gastrosteus spinachia at the St. Andrews Marine Laboratory.-E. E. PRINCE, Report Brit. Assoc., 1885, p. 1093, printed in full with 1 Plate, Ann. Nat. Hist., Dec., 1885.

$14 a$ and 15. On the Reproduction of the Common Mussel.-JoнN Wilson, Report, Brit. Assoc., 1885, p. 1094, and Report Fishery Board for Scotland, 1886.

16. On Golfingia McIntoshii, a new Sipunculus from the Neighbourbood of St. Andrews.-Prof. RAY Lankester, M.A., LL.D., F.R.S., \&c., Trans. Lin. Soc., vol. ii, pt. 16. (2 Plates.)

17. Notes from the St. Andrews Laboratory, IV. On the Structure of the Tunny. (1 Plate.)-Prof. McIN Tosh, Ann. Nat. Hist., A pril, 1886.

18. On the British Weevers, the Bib, and the Poor Cod.-Ibid., Ann. Nat. Hist., May. 1886.

19. Early Stages in the Development of the Food-Fishes.-E. E. Prince, Ann. Nat. Hist., May 1886.

20. Further Remarks on the Tunny.-Prof. McIntosh, Ann. Nat. Hist., June, 1886.

21. Remarks on the Eggs of Marine Fishes.-Ibid., Nature, 1886.

22. On the Presence of Oleaginous Spheres in the Yolk of Teleostean Ova.-E. E. Prince, Ann. Nat. Hist., Ang., 1886.

23. Points in the Development of the Pectoral Fin and Girdle in Teleosteans -E. E. PrinCE, Report, Brit. Assoc., 1866, p. 697.

24. Sume Remarks on the Egg-Membranes of Osseous Fishes.-Dr. $\mathbf{R}$. ScharfF, Ibid., p. 698.

25. Note on a Peculiar Medusa (Thaumantias) from St. Andrews Bay. -Prof. McIntosh, Ibid., p. 710.

26. On the Structure of the Tail in Myxine-Prof. Clemand, M.D., LL.D., F.R.S., Report Fishery Board, 1886, p. 211.

27. Report of the Committee for the Purpose of Continuing the Researches on Food-Fishes and Invertebrates at the St. Andrews Marine Laboratory.-Report Brit. Assoc., 1886.

28. Notes from the St. Andrews Marine Laboratory, V. On the Paternal Instincts of Cyclopterus lumpus, \&c.-PROF. McInTOSH, Ann. Nat. Hist., August, 1886.

29. Notes from the St. Andrew's Marine Iaboratory, VI. On the very Young Cod and other Food-Fishes.-PROF. McIntosh, Ann. Nat. Hist., Oct., 1886.

30. On some Experiments in Preserving Mussels for Bait.-Report Fishery Board for 1886 (published 1887).

31. On the Intra-Ovarian Eggs of Osseous Fishes.-Dr. R. ScharfF, Proceed. Roy. Soc., 1887, and Quart. Journ. Micros. Sci., Aug. 1887. (1 Plate. 4to.)

32. On the Pelagic Fauna of our Shores in its Relation to the Nourishment of the young Food-Fishes.-Prof. Mclntosh, Ann. Nat. Hist., Feb. 1887.

33. Notes from the St. Andrews Marine Laboratory, VII. A. On the Occurrence of Peculiar Gelatinous Bodies in Profusion. B. On Suncoryne decipiens, Dujardin. c. On the Commensalistic Habits 
of the Larval Forms of Peachia. D. On the Presence of Swarms of Appendicularias. E. On the Occurrence of Clione borealis, Pall.-Ibid., Ann. Nat. Hist., Aug., 1887.

34. Notes from the St. Andrews Marine Laboratory, VIII. A. On a Post-larval Labrus, with Remarks on the Colour of Pelvic Fins. B. On the Post-larval Condition of Liparis. c. On a Peculiar Teleostean Yolk-sac. D. General Remarks on Post-larval FoodFishes. -Ibid., Ann. Nat. Hist., Oct., 1887.

35. On some Rare and Remarkable Forms at St. Andrews Marine Laboratory.-Prof. McIntost, Meeting Brit. Assoc., 1887.

36. On the Development of the Ovary and Oviduct in Certain Osseous Fishes.-E. E. Prince, Ibid., 1887.

37. On the so-called Luminous Organs of Maurolicus Pennantii.-E. E. PrINCE, Report Brit. Assoc., 1887, p. 769.

38. On the Ova of Tomopteris onisciformis, Esch.-E. E. Prince, Report Brit. Assoc., 1887, p. 769.

39. On the Ciliated Organs of Tomopteris.-E.E. Prince, Ibid., p. 769.

40. The Emigration of Amœeboid Corpuscles in the Star fish. - HERBERT E. Durban, B.A., lately Vintnor Exhibitioner, King's College, Cambridge, Proceed. Roy. Soc., vol. 43, p. 327. (1 Plate.)

41. Note on the Madreporite of Cribrella oculata-Ibid., Proceed. Roy. Soc., vol. 4:3, p. 330.

42. On the Reproduction and Development of the Common Mussel. (three 4to Plates).-JoHN WILson, B.Sc., Demonstrator of Zoology, St. Andrews University, V, Report, Fishery Board for Scotlind, p. 247, 1887.

43. The Significance of the Yolk in the Eggs of Osseous Fishes.-E. E. Prince.-Ann. Nat. Hist., July, 1887. (1 Plate.)

\section{Not yet Published.}

44. On the Development of the Food-Fishes and Others, with 31 Plates, 4to.-Prof. McIntosi and E. E. Prince, St. Andrews Marine Laboratory. Ready for communication to the R. S. E.

45. On the Electrical Organs of the Skate-Prof. Burdon SaNDerson and F. Gotch, Esq, M.B., \&c., Proc. R. S., 1888.

46. On the Minute Structure of the Teleostean Eye from its Early Embryonic Condition Onward.-Dr. Marcus Guns, M.R.C.S., \&c. Vide, for abstract ensuing Report, Fishery Board fol Scotland. 